\title{
Type VI Secretion Systems of Erwinia amylovora Contribute to Bacterial Competition, Virulence, and Exopolysaccharide Production
}

\author{
Yanli Tian, Yuqiang Zhao, Linye Shi, Zhongli Cui, Baishi Hu, and Youfu Zhao
}

First, third, and fifth authors: College of Plant Protection and Key Laboratory of Integrated Management of Crop Diseases and Pests, Ministry of Education, Nanjing Agricultural University, Nanjing 210095, China; second author: Institute of Botany, Jiangsu Province and the Chinese Academy of Sciences (Nanjing Botanical Garden Mem. Sun Yat-Sen), Nanjing 210014, China; fourth author: College of Life Sciences and Key Laboratory of Agricultural Environmental Microbiology, Ministry of Agriculture, Nanjing Agricultural University, Nanjing 210095, China; and sixth author: Department of Crop Sciences, University of Illinois at Urbana-Champaign, Urbana.

Accepted for publication 10 February 2017.

\begin{abstract}
The type VI secretion system (T6SS) plays a major role in mediating interbacterial competition and might contribute to virulence in plant pathogenic bacteria. However, the role of T6SS in Erwinia amylovora remains unknown. In this study, 33 deletion mutants within three T6SS clusters were generated in E. amylovora strain NCPPB1665. Our results showed that all 33 mutants displayed reduced antibacterial activities against Escherichia coli as

virulence on immature pear fruit as compared with that of the WT strain. Among them, 6, 1, and 12 genes belonged to T6SS-1, T6SS-2, and T6SS-3 clusters, respectively. Interestingly, these 19 mutants also produced less amylovoran or levan or both. These findings suggest that E. amylovora T6SS play a role in bacterial competition and virulence possibly by influencing exopolysaccharide production.
\end{abstract} compared with that of the wild-type (WT) strain, indicating that Erwinia amylovora T6SS are functional. Of the 33 mutants, 19 exhibited reduced

Fire blight, caused by the bacterium Erwinia amylovora, is a destructive bacterial disease of apple and pear as well as other rosaceous plants. Since the first reports of fire blight in the Hudson Valley of New York, the pathogen has continued to spread around the world and has now reached Central and East Asia, the origin of apple and pear germplasms (Jock et al. 2002; Myung et al. 2016; van der Zwet 2006; Vanneste 2000). The quarantine status of E. amylovora in many countries leads to further economic losses due to strict international trade regulations (Calvin and Krissoff 1998).

Gram-negative bacterial pathogens utilize at least six protein secretion systems to secret effector proteins (Christie et al. 2005; Cornelis 2006; Segal et al. 2005). Among them, type VI secretion system (T6SS) is a unique system in proteobacteria (Bingle et al. 2008). The typical T6SS loci normally consists of 15 to 25 genes that can be divided into secreted proteins, such as hemolysin coregulated protein (Hcp) and valine-glycine repeat protein (VgrG), and nonsecreted core apparatus or transport proteins, including a ClpV family of an AAA+ ATPase (Leung et al. 2011). A conserved 13 essential genes are shared by T6SS clusters (Boyer et al. 2009). It has been suggested that the T6SS injection machine appears as an inverted phage tail on the surface of the bacterial cell (Records 2011). VgrG proteins have a trimeric phage tail spike-like structure similar to the T4 bacteriophage gp27 and gp5 complex (Pukatzki et al. 2009), whereas Hcp from Pseudomonas aeruginosa forms hexameric rings that stack to form the extracellular and periplasmic tubule (Pukatzki et al. 2007). Small proline-alanine-alanine-arginine repeat proteins (PAAR proteins), or PAAR domains within larger proteins, interact

Corresponding authors: B. Hu; E-mail address: hbs@njau.edu.cn; and Y. Zhao; E-mail address: zhao888@illinois.edu

Y. Tian and Y. Zhao contributed equally to this research.

*The $\boldsymbol{e}$-Xtra logo stands for "electronic extra" and indicates that one supplementary figure and three supplementary tables are published online.

(C) 2017 The American Phytopathological Society
Additional keywords: protein secretion system.

with VgrG to form a final sharp tip on the spike (Shneider et al. 2013). In Vibrio cholera (Records 2011), VipA and VipB form a complex of tubular, cogwheel-like structures. In both V. cholerae and $P$. aeruginosa, Hcp and VgrG proteins have been proposed to act as effectors associated with cytotoxicity (Mougous et al. 2006; Pukatzki et al. 2006). In addition, it has been reported that mutation of vca0107 (tssB), vca0108 (tssC), vca0111 (tssG), vca0114 (tssK), and vca0120 $(t s s M)$ in $V$. cholera did not affect Hcp expression but Hcp secretion was abolished in those mutants (Bönemann et al. 2009; Ishikawa et al. 2012; Zheng et al. 2011). Silverman et al. (2011) showed that T6SS activity was negatively regulated by $P A 0076$ (impM) in P. aeruginosa.

T6SS gene clusters have been identified in at least 100 bacterial genomes (Records 2011). Among them, approximately one-third contain multiple T6SS, ranging from two to six (Boyer et al. 2009). Among the sequenced E. amylovora genomes, three T6SS gene clusters were identified (De Maayer et al. 2011; Mann et al. 2013; Smits et al. 2010) (Fig. 1). In E. amylovora strain CFBP 1430, T6SS-1 (Eamy_3028-Eamy_3000), T6SS-2 (Eamy_1623Eamy_1620), and T6SS-3 (Eamy_3228-Eamy_3201) contain 27, 4, and 31 genes, respectively (De Maayer et al. 2011). Both T6SS-1 and T6SS-3 clusters encode approximately 15 core T6SS genes. Among them, at least three encode effector proteins (Hcp and VgrG) (De Maayer et al. 2011; Smits et al. 2010). Comparative genomic analysis revealed that variation between strains of E. amylovora is primarily found within the nonconserved $h c p$ and $v g r G$ islands of T6SS-1 regions II and IV and T6SS-3 region IV (De Maayer et al. 2011; Sarris et al. 2012). The T6SS-3 cluster is identified only in E. amylovora but is absent in other related Erwinia spp. (Mann et al. 2013).

Previous studies also suggested that T6SS may be involved in virulence of various animal and human pathogens, including $V$. cholerae, P. aeruginosa, Edwardsiella tarda, Salmonella enteric serovar gallinarum, and avian pathogenic Escherichia coli (Aschtgen et al. 2010; Blondel et al. 2010; Filloux et al. 2008; Hsu et al. 2009; Zheng and Leung 2007), as well as plant pathogens, including Agrobacterium tumefaciens, Pectobacterium atrosepticum, Pseudomonas syringae, Pantoea ananatis, Ralstonia solanacearum, Rhizobium 
leguminosaum, and Acidovorax citrulli (Bingle et al. 2008; Bröms et al. 2013; Mattinen et al. 2007; Records and Gross 2010; Shyntum et al. 2015; Tian et al. 2015; Wu et al. 2008;). However, the role of T6SS in Erwinia amylovora remains unknown.

The objective of this study was to determine the role of E. amylovora T6SS in virulence and bacterial competition. Our results demonstrated that T6SS are involved in bacterial competition and played a role in virulence possibly by influencing exopolysaccharide (EPS) production.

\section{MATERIALS AND METHODS}

Bacterial stains and culture media. Bacterial strains and plasmids used in this study are listed in Table 1. The Luria-Bertani (LB) medium is used routinely for culturing E. amylovora. When necessary, the following antibiotics were added to the medium: gentamicin at $50 \mu \mathrm{g} / \mathrm{ml}$ and rifampicin at $100 \mu \mathrm{g} / \mathrm{ml}$. Amylovoran production was determined by growing bacteria in $3 \mathrm{~g}$ of $\mathrm{KH}_{2} \mathrm{PO}_{4}$, $7 \mathrm{~g}$ of $\mathrm{K}_{2} \mathrm{HPO}_{4}, 1 \mathrm{~g}$ of $\left(\mathrm{NH}_{4}\right)_{2} \mathrm{SO}_{4}, 2 \mathrm{ml}$ of glycerol, $0.5 \mathrm{~g}$ of citric acid, and $0.03 \mathrm{~g}$ of $\mathrm{MgSO}_{4}$ (MBMA medium) plus $1 \%$ sorbitol (Bellemann et al. 1994; Zhao et al. 2009).

DNA manipulation and sequence analysis. Deletion mutants of T6SS core genes were generated by the $s a c B$-based allele replacement method, as described previously (Zou et al. 2011). Deletion mutants were confirmed by polymerase chain reaction (PCR) amplification using primers flanking the genes of interest. Primer sequences used for mutant construction and confirmation are listed in Supplementary Table S1. The resultant constructs were introduced into Escherichia coli S17-1( $\lambda$ pir) for use in biparental mating with Erwinia amylovora strain NCPPB1665. For complementation, the coding regions of these genes were amplified by PCR using the primers listed in Supplementary Table S1 and cloned into the expression vector pBBR1MCS-5. The resulting constructs were transferred into the corresponding mutants by biparental mating.

Antibacterial competition assays. Antibacterial competition assays were conducted as described previously (Hachani et al. 2013; McNally et al. 2012). In brief, an Escherichia coli recipient cell was made by transforming E. coli DH5 $\alpha$ cells with a plasmid pMD19-T allowing the a-complementation of the lacZ gene. The Erwinia amylovora attacker strain and the Escherichia coli DH5 $\alpha$ (lacZ) target strain (both at an optical density at $600 \mathrm{~nm}\left[\mathrm{OD}_{600}\right]=0.5$ ) were mixed at a ratio of $1: 1$. The "no Erwinia amylovora" control mixture contained sterile LB and Escherichia coli DH5 $\alpha$ (lacZ) at a $1: 1$ ratio. For the quantification of the competition assay, $20 \mu \mathrm{l}$ of this mixture was spotted onto solid LB medium for $5 \mathrm{~h}$ at $28^{\circ} \mathrm{C}$. The CFU of surviving E. coli $\mathrm{DH} 5 \alpha$ (lacZ) was measured by a serial dilution and selective growth on LB agar plates containing rifampicin at $100 \mu \mathrm{g} / \mathrm{ml}$ (for Erwinia amylovora) and ampicillin at $100 \mu \mathrm{g} / \mathrm{ml}$ (for Escherichia coli), respectively. The experiment was repeated three times.

Virulence assay on immature pear fruit. Virulence tests on immature pear fruit ('Cuiguan') were performed as described previously (McNally et al. 2012; Wang et al. 2012). Briefly, bacterial cells were grown overnight in LB broth, harvested by centrifugation, and washed with double-distilled water $\left(\mathrm{ddH}_{2} \mathrm{O}\right)$ three times. After the final wash, the pellet was resuspended in $\mathrm{ddH}_{2} \mathrm{O}$ $\left(\mathrm{OD}_{600}=0.1\right.$ and then diluted 100 -fold $)$. Immature pear fruit were surface sterilized and pricked with a sterile needle. The wounded fruit were inoculated with $2 \mu \mathrm{l}$ of cell suspensions and incubated at $100 \%$ relative humidity at $28^{\circ} \mathrm{C}$. Symptoms were recorded at 8 days postinoculation. For each bacterial strain, three fruit were inoculated. Virulence was determined quantitatively via the percentage necrosis, calculated as the surface area of pear relative to the surface area of necrotic and water-soaked tissue. The experiment was repeated three times with similar results.

Cetylpyrimidinium chloride assay for determining amylovoran concentration. The amylovoran concentration in supernatants of bacterial cultures was quantitatively determined by a turbidity assay with cetylpyrimidinium chloride (CPC), as previously described (Bellemann et al. 1994; Wang et al. 2012; Zhao et al. 2009). Briefly, bacterial cells were grown overnight in LB broth, harvested by centrifugation, and washed with $\mathrm{ddH}_{2} \mathrm{O}$ three times. After the final wash, the pellet was resuspended in $200 \mu \mathrm{l}$ of $\mathrm{ddH}_{2} \mathrm{O}$. In total, $100 \mu \mathrm{l}$ of bacterial suspension was inoculated into $10 \mathrm{ml}$ of MBMA medium with $1 \%$ sorbitol. Bacterial cells $(1 \mathrm{ml})$ were pelleted 2 days after inoculation at $28^{\circ} \mathrm{C}$ with shaking. Following centrifugation, $50 \mu \mathrm{l}$ of CPC at $50 \mathrm{mg} / \mathrm{ml}$ was added to $1 \mathrm{ml}$ of supernatant. After $10 \mathrm{~min}$ of incubation at room temperature, amylovoran concentration was determined by measuring $\mathrm{OD}_{600}$ turbidity. The final concentration of amylovoran production was normalized for a cell density of 1.0. For each strain tested, the experiment was repeated three times.

Levansucrase assays. The secreted levansucrase activity was measured according to Hildebrand et al. (2006). Briefly, bacteria were cultured overnight in LB broth, and bacterial cells were removed by centrifugation. In total, $500 \mu \mathrm{l}$ of supernatant was mixed with $500 \mu \mathrm{l}$ of $100 \mathrm{mM}$ potassium phosphate buffer ( $\mathrm{pH} 7.0), 2 \mathrm{M}$ sucrose and $0.05 \%$ sodium azide and incubated at $37^{\circ} \mathrm{C}$ for $3 \mathrm{~h}$. Turbidity was measured at $600 \mathrm{~nm}$ and normalized for a cell density of 1.0. For each strain tested, the experiment was repeated three times.

RNA isolation. For ams gene expression, bacterial strains were grown overnight in LB medium, diluted in $5 \mathrm{ml}$ of MBMA medium at an $\mathrm{OD}_{600}$ of 0.005 , and incubated for $18 \mathrm{~h}$ of growth in MBMA
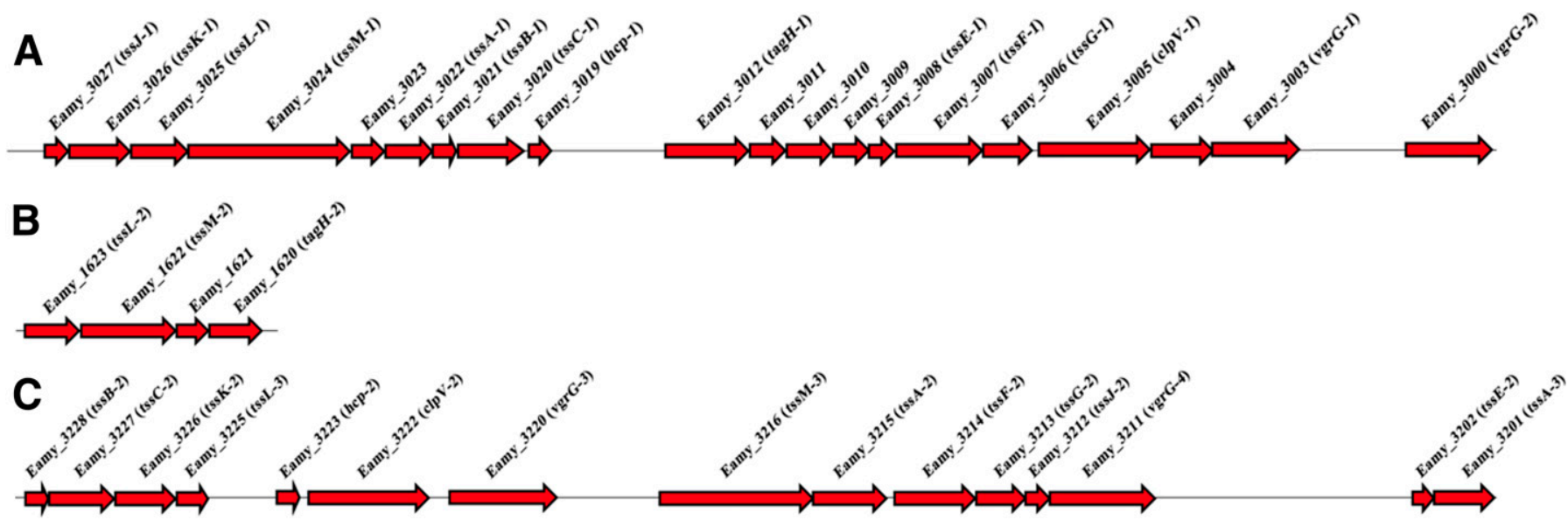

Fig. 1. Arrangement of Erwinia amylovora CFBP 1430 type VI secretion system (T6SS) gene clusters indicating the relative position of gene homologs. A, T6SS gene cluster 1; B, T6SS gene cluster 2; and $\mathbf{C}$, T6SS gene cluster 3. 
medium at $28^{\circ} \mathrm{C}$. For $l s c$ gene expression, Erwinia amylovora strains were cultured overnight in LB broth as described above. RNA Protect Reagent ( $2 \mathrm{ml}$ ) (Qiagen) was added to $1 \mathrm{ml}$ of bacterial culture (at $\mathrm{OD}_{600}$ of approximately 0.5 to 0.8 ) to stabilize RNA. Cells were harvested by centrifugation for $10 \mathrm{~min}$ at $4,000 \times g$ and RNA was extracted using Qiagen Bacterial RNA Protect Mini Kit as recommended by the manufacturer (Qiagen). On-column DNA digestion was performed using Qiagen DNase. RNA integrity was confirmed by electrophoresis on $1.2 \%$ agarose gels.
Quantitative real-time PCR. Relative quantitative real-time PCR was carried out using the SYBR Premix EX Tag II kit (TaKaRa) in an ABI PRISM 7500 Real-Time PCR System (Applied Biosystems). 16S ribosomal RNA (rRNA) was used as an endogenous control. Primer sequences are listed in Supplementary Table S2. Primer pairs 16SF-16SR, amsBF-amsBR, amsDF-amsDR, amsEF-amsER, amsGF-amsGR, amsJF-amsJR, and lscF-lscR were used to detect expression of $16 \mathrm{~S}$ rRNA, ams $, a m s D, a m s E, a m s G$, $a m s J$, and $l s c$ genes, respectively. Then, $2 \mu \mathrm{g}$ of each RNA sample

TABLE 1. Bacterial strains and plasmids used in this study

\begin{tabular}{|c|c|c|}
\hline Bacteria or plasmids & Relevant characteristics ${ }^{\mathrm{z}}$ & Source or reference \\
\hline \multicolumn{3}{|l|}{ Erwinia amylovora } \\
\hline NCPPB1665 & Wild-type, RifR & Lab collection \\
\hline$\Delta v g r G-2$ & $\operatorname{vgr} G-2$ knockout mutant & This study \\
\hline$\Delta v \operatorname{grG}-1$ & $\operatorname{vgr} G-1$ knockout mutant & This study \\
\hline$\Delta c l p V-1$ & $\operatorname{clp} V-1$ knockout mutant & This study \\
\hline$\Delta t s s G-1$ & tss $G-1$ knockout mutant & This study \\
\hline$\Delta t s s F-1$ & tss $F-1$ knockout mutant & This study \\
\hline$\Delta t s s E-1$ & tssE-1 knockout mutant & This study \\
\hline$\Delta \operatorname{tag} H-1$ & tagH-1 knockout mutant & This study \\
\hline$\Delta h c p-1$ & hcp-1 knockout mutant & This study \\
\hline$\Delta t s s C-1$ & tss $C-1$ knockout mutant & This study \\
\hline$\Delta t s s B-1$ & tss $B-1$ knockout mutant & This study \\
\hline$\Delta t s s A-1$ & tss $A-1$ knockout mutant & This study \\
\hline$\Delta t s s M-1$ & tss $M-1$ knockout mutant & This study \\
\hline$\Delta t s s L-1$ & tss $L-1$ knockout mutant & This study \\
\hline$\Delta t s s K-1$ & tss $K-1$ knockout mutant & This study \\
\hline$\Delta t s s J-1$ & tssJ-1 knockout mutant & This study \\
\hline$\Delta \operatorname{tag} H-2$ & tagH-2 knockout mutant & This study \\
\hline$\Delta t s s M-2$ & tss $M-2$ knockout mutant & This study \\
\hline$\Delta t s s L-2$ & tss $L-2$ knockout mutant & This study \\
\hline$\Delta t s s A-3$ & tss $A-3$ knockout mutant & This study \\
\hline$\Delta t s s E-2$ & tssE-2 knockout mutant & This study \\
\hline$\Delta v g r G-4$ & $\operatorname{vgr} G-4$ knockout mutant & This study \\
\hline$\Delta t s s J-2$ & tssJ-2 knockout mutant & This study \\
\hline$\Delta t s s G-2$ & $t s s G-2$ knockout mutant & This study \\
\hline$\Delta t s s F-2$ & $t s s F-2$ knockout mutant & This study \\
\hline$\Delta t s s A-2$ & tss A-2 knockout mutant & This study \\
\hline$\Delta t s s M-3$ & tss $M-3$ knockout mutant & This study \\
\hline$\Delta v g r G-3$ & $\operatorname{vgr} G-3$ knockout mutant & This study \\
\hline$\Delta c l p V-2$ & $\operatorname{clp} V-2$ knockout mutant & This study \\
\hline$\Delta h c p-2$ & hcp-2 knockout mutant & This study \\
\hline$\Delta t s s L-3$ & tss L-3 knockout mutant & This study \\
\hline$\Delta t s s K-2$ & tss $K-2$ knockout mutant & This study \\
\hline$\Delta t s s C-2$ & tss $C-2$ knockout mutant & This study \\
\hline$\Delta t s s B-2$ & tss $B-2$ knockout mutant & This study \\
\hline \multicolumn{3}{|l|}{ Escherichia coli } \\
\hline DH5 $\alpha(\lambda$ pir $)$ & Ф80 lacZ M15, $\Delta($ lacZYA-argF) U169. recA1, endA1.thi-1 & TaKaRa \\
\hline S17-1( $\lambda$ pir $)$ & Apir pro hsdR, recA & Simon et al. 1983 \\
\hline \multicolumn{3}{|l|}{ Plasmids } \\
\hline pMD19-T & "TA" Cloning vector & TaKaRa \\
\hline pEX18GM & Suicide vector with a $s a c B$ gene, $\mathrm{Gm}^{\mathrm{R}}$ & Hoang et al. 1998 \\
\hline pBBR1MCS-5 & Broad-host-range cloning vector, $\mathrm{Gm}^{\mathrm{R}}$ & Kovach et al. 1995 \\
\hline pVgrG2 & $\mathrm{Gm}^{\mathrm{R}}$, a 2,764-bp DNA fragment containing $v g r G-2$ gene and its promoter in pBBR1MCS-5 & This study \\
\hline pVgrG1 & $\mathrm{Gm}^{\mathrm{R}}$, a 2,503-bp DNA fragment containing $\operatorname{vgr} G-1$ gene and its promoter in pBBR1MCS-5 & This study \\
\hline pTssG1 & $\mathrm{Gm}^{\mathrm{R}}$, a $1,484-\mathrm{bp}$ DNA fragment containing $t s s G-1$ gene and its promoter in pBBR $1 \mathrm{MCS}-5$ & This study \\
\hline pTagH1 & $\mathrm{Gm}^{\mathrm{R}}$, a 2,085-bp DNA fragment containing tagH-1 gene and its promoter in pBBR1MCS-5 & This study \\
\hline pTssM1 & $\mathrm{Gm}^{\mathrm{R}}$, a 4,133 -bp DNA fragment containing $t s s M-1$ gene and its promoter in pBBR1MCS-5 & This study \\
\hline pTssK1 & $\mathrm{Gm}^{\mathrm{R}}$, a $1,735-\mathrm{bp}$ DNA fragment containing $t s s K-1$ gene and its promoter in pBBR $1 \mathrm{MCS}-5$ & This study \\
\hline pTagH2 & $\mathrm{Gm}^{\mathrm{R}}$, a $1,585-\mathrm{bp}$ DNA fragment containing tagH-2 gene and its promoter in pBBR1MCS-5 & This study \\
\hline pTssA3 & $\mathrm{Gm}^{\mathrm{R}}$, a 1,916-bp DNA fragment containing $t s s A-3$ gene and its promoter in pBBR1MCS-5 & This study \\
\hline pTssE2 & $\mathrm{Gm}^{\mathrm{R}}$, a 705-bp DNA fragment containing tssE-2 gene and its promoter in pBBR1MCS-5 & This study \\
\hline pTssJ2 & $\mathrm{Gm}^{\mathrm{R}}$, a 828-bp DNA fragment containing tssJ-2 gene and its promoter in pBBR1MCS-5 & This study \\
\hline pTssG2 & $\mathrm{Gm}^{\mathrm{R}}$, a $1,634-\mathrm{bp}$ DNA fragment containing $t s s G-2$ gene and its promoter in pBBR1MCS-5 & This study \\
\hline pTssF2 & $\mathrm{Gm}^{\mathrm{R}}$, a 1,974-bp DNA fragment containing $t s s F-2$ gene and its promoter in pBBR $1 \mathrm{MCS}-5$ & This study \\
\hline pTssA2 & $\mathrm{Gm}^{\mathrm{R}}$, a 1,974-bp DNA fragment containing $t s s A-2$ gene and its promoter in pBBR1MCS-5 & This study \\
\hline pTssM3 & $\mathrm{Gm}^{\mathrm{R}}$, a 3,783-bp DNA fragment containing $t s s M-3$ gene and its promoter in pBBR1MCS-5 & This study \\
\hline pClpV2 & $\mathrm{Gm}^{\mathrm{R}}$, a 2,783-bp DNA fragment containing $c l p V-2$ gene and its promoter in pBBR1MCS-5 & This study \\
\hline pTssL3 & $\mathrm{Gm}^{\mathrm{R}}$, a 939-bp DNA fragment containing tss $L-3$ gene and its promoter in pBBR1MCS-5 & This study \\
\hline pTssK2 & $\mathrm{Gm}^{\mathrm{R}}$, a 1,950 -bp DNA fragment containing tss $K-2$ gene and its promoter in pBBR1MCS-5 & This study \\
\hline pTssC2 & $\mathrm{Gm}^{\mathrm{R}}$, a 2,078-bp DNA fragment containing $t s s C-2$ gene and its promoter in pBBR1MCS-5 & This study \\
\hline pTssB2 & $\mathrm{Gm}^{\mathrm{R}}$, a 1,064-bp DNA fragment containing $t s s B-2$ gene and its promoter in pBBR1MCS-5 & This study \\
\hline
\end{tabular}

${ }^{\mathrm{z}} \mathrm{Gm}^{\mathrm{R}}$ and $\mathrm{Rif}^{\mathrm{R}}$ indicate resistance to gentamicin and rifampicin, respectively. 
was used to synthesize cDNA with a cDNA synthesis kit (TaKaRa). Quantitative real-time PCR amplifications were carried out at $50^{\circ} \mathrm{C}$ for $2 \mathrm{~min}, 95^{\circ} \mathrm{C}$ for $10 \mathrm{~min}$, followed by 40 cycles of $95^{\circ} \mathrm{C}$ for $15 \mathrm{~s}$ and $60^{\circ} \mathrm{C}$ for $1 \mathrm{~min}$, and a final dissociation curve analysis step from 65 to $95^{\circ} \mathrm{C}$. The experiment was repeated three times. The transcriptional levels of $a m s B$, amsD, amsE, ams $G, a m s J$, and $l s c$ in the wild-type (WT) and mutant strains was assessed and compared.

Data analysis. All analyses were conducted using SPSS 14.0 (SPSS Inc.). The one-way student's $t$ test $(P=0.05)$ was used to determine significant differences in disease severity, pathogenicityrelated phenotypes, and gene expressions among WT and mutant strains of E. amylovora.

\section{RESULTS}

T6SS of $E$. amylovora play a role in antibacterial activities. To test the contribution of T6SS to the antibacterial properties of Erwinia amylovora, we examined the abilities of 33 T6SS mutants in competitively killing Escherichia coli $\mathrm{DH} 5 \alpha$ on agar plates. Survival of Escherichia coli was lower when coincubated with the Erwinia amylovora WT, whereas survival of Escherichia coli was greatly increased when coincubated with all 33 mutants (Fig. 2). The survival of Escherichia coli was decreased in complementation strains (Supplementary Table S3). These results indicated that T6SS in Erwinia amylovora play a role in bacterial competition, suggesting that T6SS in E. amylovora are functional.

T6SS of $E$. amylovora contribute to virulence. Virulence tests of the 33 T6SS mutants on immature pear fruit showed that 19 mutants $(\Delta t s s A-2, \Delta t s s A-3, \Delta t s s B-2, \Delta t s s C-2, \Delta t s s E-2, \Delta t s s F-2$, $\Delta t s s G-1, \Delta t s s G-2, \Delta t s s J-2, \Delta t s s K-1, \Delta t s s K-2, \Delta t s s L-3, \Delta t s s M-1$, $\Delta t s s M-3, \Delta v g r G-1, \Delta v g r G-2, \Delta \operatorname{clpV}-2, \Delta \operatorname{tag} H-1$, and $\Delta$ tag $H$-2) were either nonpathogenic or their virulence was reduced on immature pear fruit as compared with that of the WT strain (Fig. 3). Among them, 6, 1, and 12 belong to the T6SS-1, T6SS-2, and T6SS-3 clusters, respectively. Complementation of these mutants partially or completely recovered their virulence to the level of the WT (Fig. 3 ). We have compared the growth of the WT and these mutants (Supplementary Fig. S1), and found that the mutants were not impaired in growth. The other 14 mutants $(\Delta t s s A-1, \Delta t s s B-1, \Delta t s s C-1, \Delta t s s E-1$, $\Delta t s s F-1, \Delta t s s J-1, \Delta t s s L-1, \Delta t s s L-2, \Delta t s s M-2, \Delta c l p V-1, \Delta h c p-1, \Delta h c p-2$, $\Delta v g r G-3$, and $\Delta v g r G-4$ ) were as pathogenic as the WT strain (data not shown). These results indicated that T6SS systems of E. amylovora contribute to virulence.

T6SS affect amylovoran production. Phenotypes of the 33 deletion mutant strains were further evaluated by measuring amylovoran biosynthesis in vitro. Three groups of mutants exhibiting varying levels of amylovoran production in vitro were identified (Table 2). For group I, four mutants ( $\Delta t s s A-1, \Delta t s s B-1, \Delta t s s C$ - 1 , and $\Delta h c p-1$ ) showed approximately twofold increase of amylovoran production as compared with that of the WT (Table 2). Consistent with amylovoran production, amylovoran biosynthetic genes, including $a m s B$, ams $D$, amsE, ams $G$, and $a m s J$, were upregulated by two- to threefold in these four mutant strains (Table 3). For group 2, 16 mutants showed a 1.3- to 5-fold reduction in amylovoran production as compared with that of the WT; these included $\Delta t s s A$ $2, \Delta t s s A-3, \Delta t s s B-2, \Delta t s s C-2, \Delta t s s E-2, \Delta t s s F-2, \Delta t s s G-1, \Delta t s s G-2$, $\Delta t s s J-2, \Delta t s s K-1, \Delta t s s K-2, \Delta t s s L-3, \Delta t s s M-3, \Delta \operatorname{lp} V-2, \Delta v g r G-1$, and $\Delta v g r G-2$ (Table 2). Expression of amsB, amsD, amsE, ams $G$, and amsJ genes were also downregulated by two- to fivefold in these 16 mutant strains (Table 3). Amylovoran production was complemented in group 1 and 2 mutant strains. Group 3 mutants (13 mutants) did not show much difference in amylovoran production when compared with that of the WT; these included $\Delta t s s E-1$, $\Delta t s s F-1, \Delta t s s J-1, \Delta t s s L-1, \Delta t s s L-2, \Delta t s s M-1, \Delta t s s M-2, \Delta h c p-2$, $\Delta c l p V-1, \Delta \operatorname{tag} H-1, \Delta \operatorname{tag} H-2, \Delta v g r G-3$, and $\Delta v g r G-4$ (Table 2). These results indicated that T6SS influence amylovoran production in E. amylovora.

T6SS influence levan production. Levan production was also determined in WT and 33 mutants. Fourteen mutants had a twoto fourfold reduction in levan production as compared with that of the WT strain; these included $\Delta t s s K-1, \Delta t s s M-1, \Delta t s s A-1, \Delta h c p-1$, $\Delta$ tagH-1, $\Delta t s s E-1, \Delta t s s F-1, \Delta t s s G-1, \Delta t a g H-2, \Delta t s s K-2, \Delta t s s M-3$, $\Delta t s s A-2, \Delta t s s F-2$, and $\Delta t s s J-2$ (Table 2). Levan production was complemented in these mutants. Similarly, expression of the $l s c$ gene was also decreased two- to eightfold in these 14 mutants as compared with that of the WT strain (Table 3). These results indicated that T6SS positively affect levan production in E. amylovora.

\section{DISCUSSION}

In the sequenced genomes of E. amylovora strains, three T6SS gene clusters were identified (Mann et al. 2013; Smits et al. 2010). Comparison with other related Erwinia spp. on pome fruit trees indicated that T6SS-1 and T6SS-2 are shared among them, whereas T6SS-3 is present only in E. amylovora strains (Mann et al. 2013; Smits et al. 2010).Previous studies have shown that T6SS mediates interbacterial interactions (Ma et al. 2014; Schwarz et al. 2010; Shyntum et al. 2015), virulence (Pukatzki et al. 2006; Suarez et al. 2008; Zheng and Leung 2007), biofilm formation (Aschtgen et al. 2010), quorum sensing, and stress responses (Weber et al. 2009), thus enhancing their adaptation abilities to changing environmental

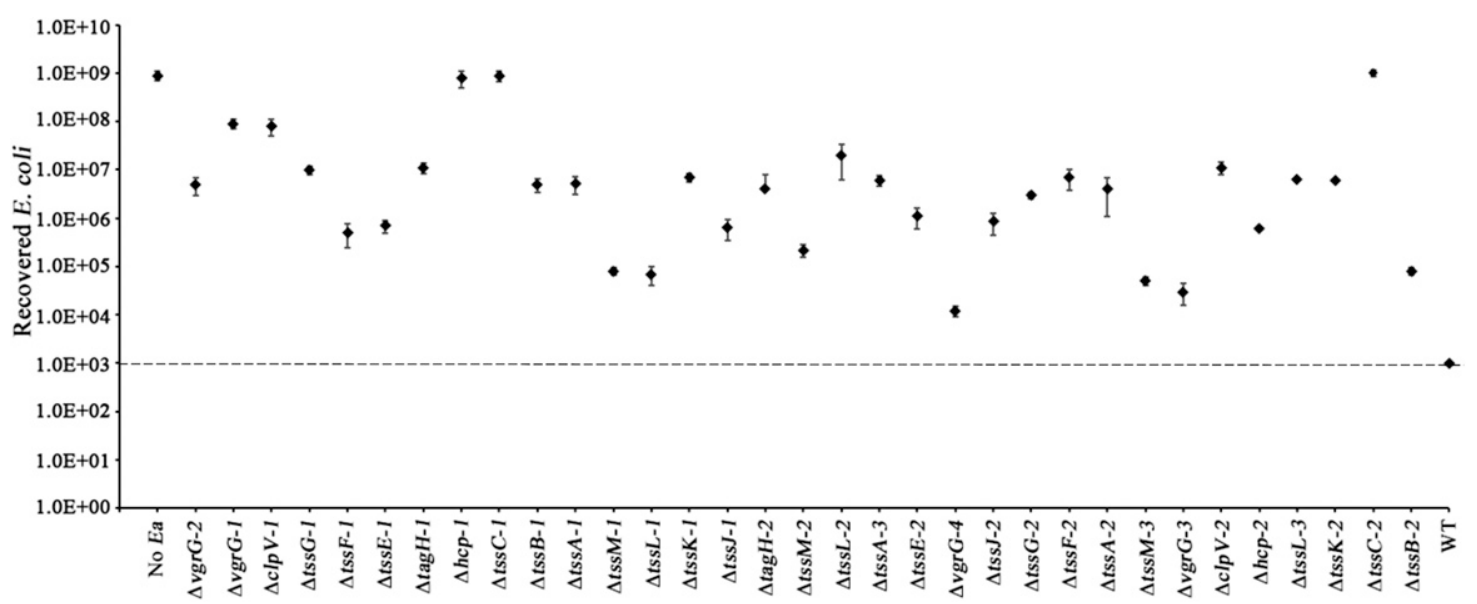

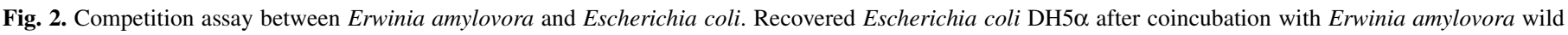

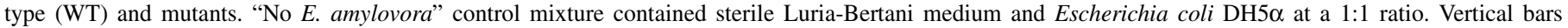
represent standard errors of the means. 
conditions (Weber et al. 2009). In this study, we characterized 33 deletion mutants of the T6SS core genes in E. amylovora strain NCPPB1665 and demonstrated that all three T6SS systems (T6SS1, T6SS-2, and T6SS-3) were involved in bacterial competition, EPS production, and virulence in the fire blight pathogen. These results also suggest that T6SS might contribute to virulence, possibly by promoting amylovoran and levan biosynthesis.

EPS has been reported to play a key role in protecting bacteria against water and nutrient loss and to bypass the plant defense system (Denny 1995; Ordax et al. 2010). E. amylovora produces two types of EPS, levan and amylovoran (Ayers et al. 1979), where amylovoran is considered to be a pathogenicity factor and levan a virulence factor
(Gross et al. 1992; Sjulin and Beer 1978; Vrancken et al. 2013). Although T6SS have been known to play a role in virulence of various animal, human, and plant pathogens, the connection between T6SS and EPS has not been reported previously (Aschtgen et al. 2010; Blondel et al. 2010; Filloux et al. 2008; Hsu et al. 2009; Mattinen et al. 2007; Records and Gross 2010; Wu et al. 2008). In this study, among the 19 T6SS mutants with reduced virulence, 7 mutants produced less amylovoran and levan, 9 produced less amylovoran, and 3 produced less levan. These results suggest the possible link between virulence reductions in the T6SS mutants with EPS production.

Accumulation of amylovoran could lead to wilting symptoms by restriction of water movement through physical blockage of

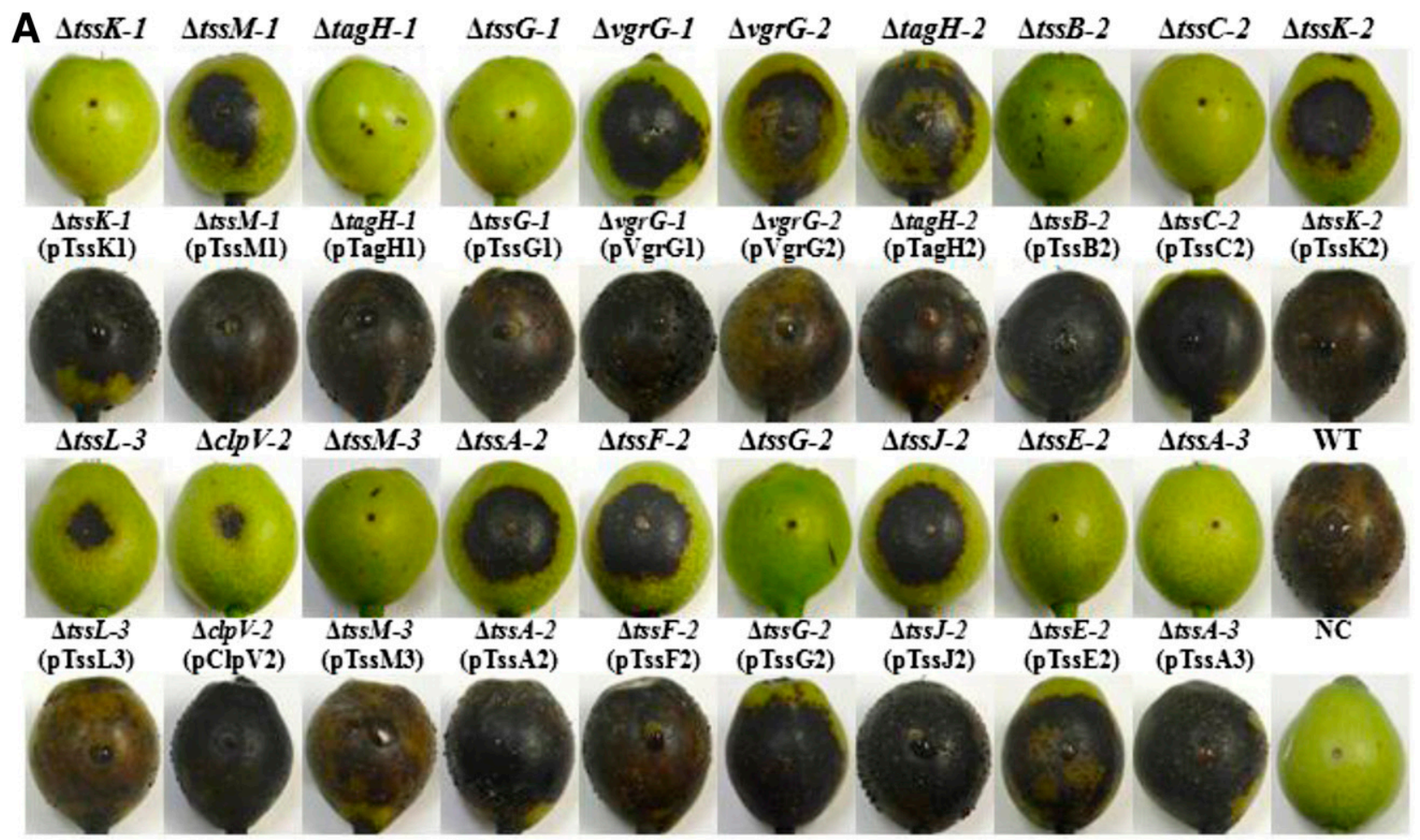

B

$\square$ Mutant or WT $\square$ Complementation

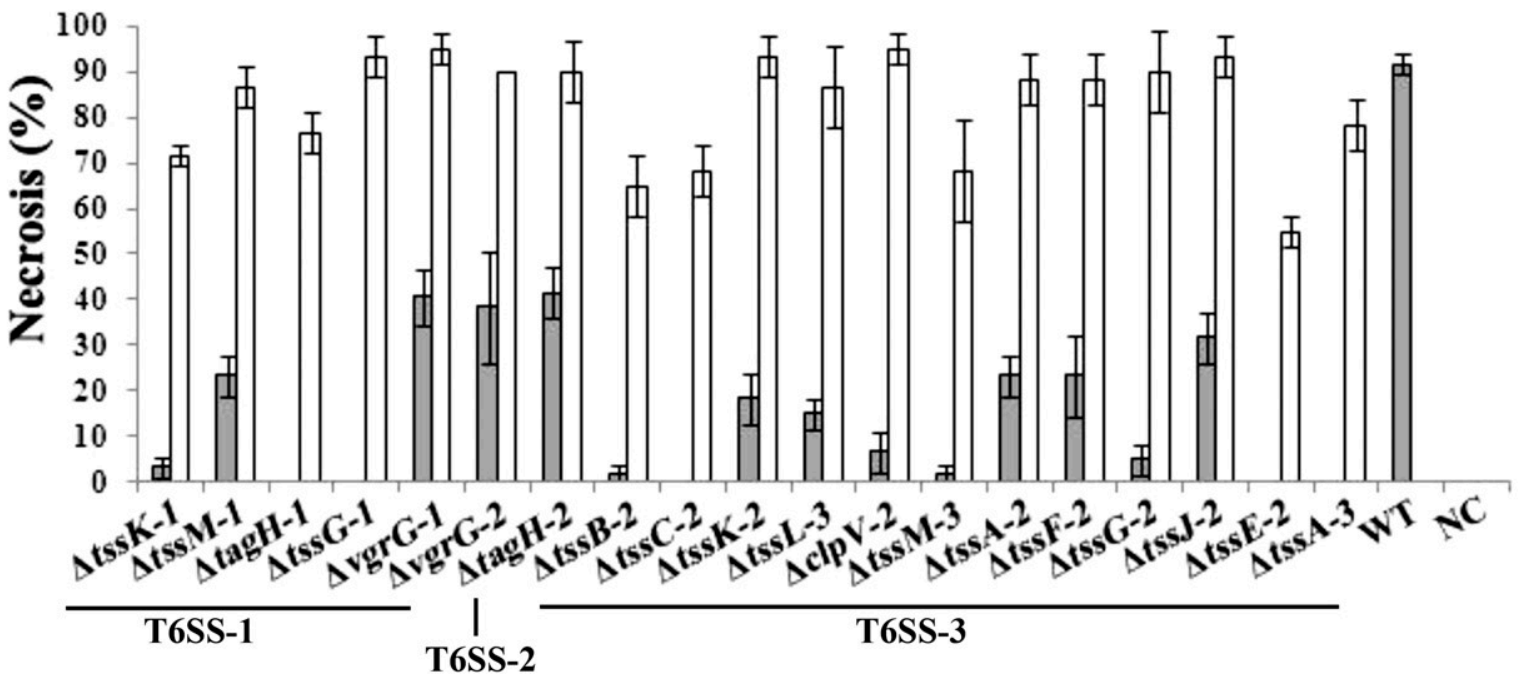

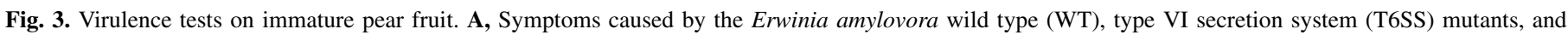

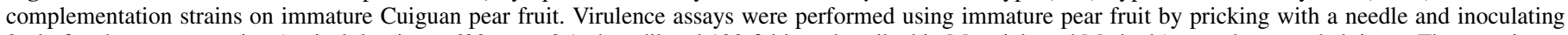

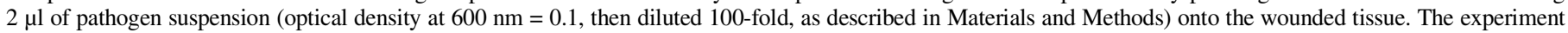

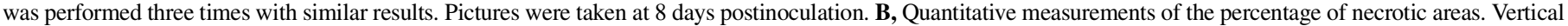
bars represent standard errors of the means. T6SS-1, -2 , and -3 indicates genes from three T6SS gene clusters. 
vascular elements in E. amylovora (Sjulin and Beer 1978). Genetic studies showed that amylovoran-deficient mutants are avirulent (Bellemann et al. 1994; Steinberger 1988) and the quantity of amylovoran produced by individual E. amylovora strains is correlated with the degree of virulence (Ayers et al. 1979). Genomewide screening of two-component signal transduction systems (TCST) identified four groups of TCST as either negative or positive regulators of amylovoran biosynthesis in E. amylovora, including the RcsBCD, GacS/GacA, and EnvZ/OmpR systems (Zhao et al. 2009). Genetic screening also identified other global regulatory genes for amylovoran biosynthesis, including AmyR, Lon protease, c-di-GMP, small RNAs, and H-NS (Eastgate et al. 1995; Edmunds et al. 2013, Hildebrand et al. 2006; Wang et al. 2012; Zeng et al. 2013). These findings suggest that regulation of amylovoran biosynthesis is highly complex. In the current study, we provided evidence that EPS production may also be under the influence of the T6SS. Though we do not have a definite answer as to why, it is tempting to speculate that T6SS may provide E. amylovora some advantage to compete with other microorganisms in an environment with limited resources, or to protect E. amylovora from other microorganisms which may also utilize T6SS to attack by producing more amylovoran or levan.

T6SS has been well established under laboratory conditions for its role in bacterial competition (Dong et al. 2013; Hood et al. 2010); recent study also indicated that $P$. ananatis T6SS-1 plays an important role in pathogenesis on onion plants and in bacterial competition (Shyntum et al. 2015). We observed similar antibacterial activity of T6SS during coculture on a solid agar surface, suggesting that E. amylovora acts through neighboring cells, as proposed for other bacteria (Dong et al. 2013; Ma et al. 2014). Because conserved T6SS effectors such as Tae and Tle are not present in the E. amylovora genome, it is still unclear whether T6SS deliver other effectors in natural communities or how T6SS in E. amylovora function in both pathogenesis and bacterial competition. Further investigation is warranted to demonstrate the molecular mechanisms.

Some genes with dual functions have been reported in previous studies (Matthysse et al. 1996; Zhang et al. 2002). For example, in addition to being involved in the attachment of Agrobacterium tumefaciens to plant cells (Matthysse et al. 1996), attM was identified to encode the nacylhomoserine lactone quorum-sensing signal molecule degradation enzyme (Zhang et al. 2002). A mutant of the attM gene showed a nonattachment phenotype and decreased virulence (Matthysse et al. 1996). Furthermore, Zhang et al. (2002) presented evidence that the enzyme encoded by attM inactivates 3OC8HSL quorum-sensing signals by hydrolysis of its homoserine lactone ring. We found that some T6SS core components influenced both EPS production and bacterial competition. Our results also indicate that all of the core genes contributed to bacterial competition. The T6SS core components form a complex transenvelope machinery which directly injects secreted effector proteins from the bacterial cytoplasm into a target cell (Boyer et al. 2009; Ho et al. 2014). It is easy to understand that all 33 core gene mutants displayed reduced antibacterial activities against Escherichia coli as compared

TABLE 2. Virulence and exopolysaccharide production of Erwinia amylovora mutants and the wild type (WT)y

\begin{tabular}{|c|c|c|c|}
\hline WT, mutant ${ }^{\mathrm{z}}$ & Virulence (\% necrotic) & Amylovoran production $\left(\mathrm{OD}_{600}\right)$ & Levan production $\left(\mathrm{OD}_{600}\right)$ \\
\hline WT & $92 \pm 2.2 \mathrm{a}$ & $1.794 \pm 0.036 \mathrm{c}$ & $0.465 \pm 0.039 a$ \\
\hline \multicolumn{4}{|l|}{ T6SS-1 } \\
\hline$\Delta v \operatorname{grG}-2$ & $38.3 \pm 12.2 b$ & $1.316 \pm \mathbf{0 . 0 9 1} \mathrm{de}$ & $0.403 \pm 0.011 \mathrm{ab}$ \\
\hline$\Delta c l p V-1$ & $81.67 \pm 5.556 \mathrm{a}$ & $1.8 \pm 0.12 \mathrm{c}$ & $0.46 \pm 0.02 \mathrm{a}$ \\
\hline$\Delta t s s G-1$ & $0 \mathrm{e}$ & $\mathbf{0 . 3 6 3} \pm \mathbf{0 . 0 3 8} g$ & $\mathbf{0 . 2 6 6} \pm \mathbf{0 . 0 3 7} \mathrm{def}$ \\
\hline$\Delta t s s F-1$ & $71.67 \pm 4.444 \mathrm{a}$ & $1.75 \pm 0.04 \mathrm{c}$ & $\mathbf{0 . 2 5 8} \pm \mathbf{0 . 0 3 1}$ def \\
\hline$\Delta t s s E-1$ & $76.67 \pm 2.222 \mathrm{a}$ & $1.773 \pm 0.071 \mathrm{c}$ & $\mathbf{0 . 0 8 3} \pm \mathbf{0 . 0 3 6} g$ \\
\hline$\Delta t s s C-1$ & $78.33 \pm 5.556 \mathrm{a}$ & $3.045 \pm 0.122 b$ & $0.369 \pm 0.012 \mathrm{ab}$ \\
\hline$\Delta t s s B-1$ & $85 \pm 6.667 \mathrm{a}$ & $3.03 \pm 0.173 b$ & $0.372 \pm 0.021 \mathrm{ab}$ \\
\hline$\Delta t s s A-1$ & $83.33 \pm 8.889 a$ & $2.933 \pm 0.038 b$ & $\mathbf{0 . 2 5 3} \pm \mathbf{0 . 0 1 6}$ def \\
\hline$\Delta t s s M-1$ & $23.33 \pm 4.444 \mathrm{~cd}$ & $1.817 \pm 0.031 \mathrm{c}$ & $\mathbf{0 . 0 8 5} \pm \mathbf{0 . 0 3 4} g$ \\
\hline$\Delta t s s L-1$ & $88.33 \pm 2.222 \mathrm{a}$ & $1.8 \pm 0.067 \mathrm{c}$ & $0.319 \pm 0.026 \mathrm{ab}$ \\
\hline$\Delta t s s K-1$ & $1.667 \pm 2.222$ e & $0.96 \pm 0.053 \mathrm{f}$ & $0.209 \pm 0.015$ ef \\
\hline$\Delta t s s J-1$ & $78.33 \pm 7.778 \mathrm{a}$ & $1.743 \pm 0.058 \mathrm{c}$ & $0.42 \pm 0.02 \mathrm{ab}$ \\
\hline \multicolumn{4}{|l|}{ T6SS-2 } \\
\hline$\Delta t s s A-3$ & $\mathbf{0} \mathrm{e}$ & $0.463 \pm 0.051 g$ & $0.448 \pm 0.018 \mathrm{a}$ \\
\hline$\Delta t s s E-2$ & $\mathbf{0} \mathrm{e}$ & $0.477 \pm 0.116 g$ & $0.435 \pm 0.011 \mathrm{a}$ \\
\hline$\Delta v \operatorname{grG}-4$ & $90 \pm 3.33 \mathrm{a}$ & $1.78 \pm 0.047 \mathrm{c}$ & $0.46 \pm 0.024 \mathrm{a}$ \\
\hline$\Delta t s s J-2$ & $31.7 \pm 5.56 c$ & $\mathbf{0 . 7 5 3} \pm \mathbf{0 . 0 8 9} f$ & $\mathbf{0 . 2 7 1} \pm \mathbf{0 . 0 2 5}$ def \\
\hline$\Delta t s s G-2$ & $5 \pm \mathbf{3 . 3 3} \mathrm{e}$ & $0.407 \pm 0.038 g$ & $0.443 \pm 0.022 \mathrm{a}$ \\
\hline$\Delta t s s F-2$ & $23.3 \pm 8.89 \mathrm{~cd}$ & $0.773 \pm 0.051 \mathrm{f}$ & $\mathbf{0 . 1 4 9} \pm \mathbf{0 . 0 3 5} f g$ \\
\hline$\Delta t s s A-2$ & $23.33 \pm 4.444 \mathrm{~cd}$ & $0.802 \pm 0.038 \mathrm{f}$ & $\mathbf{0 . 2 8 2} \pm \mathbf{0 . 0 1 6} \mathrm{def}$ \\
\hline$\Delta t s s M-3$ & $1.67 \pm 2.22 \mathrm{e}$ & $\mathbf{0 . 5 0 3} \pm \mathbf{0 . 0 3 8} g$ & $\mathbf{0 . 2 0 8} \pm \mathbf{0 . 0 5 7}$ ef \\
\hline$\Delta v g r G-3$ & $90 \pm 6.667 \mathrm{a}$ & $1.75 \pm 0.047 \mathrm{c}$ & $0.447 \pm 0.012 \mathrm{a}$ \\
\hline$\Delta c l p V-2$ & $6.67 \pm 4.44 \mathrm{de}$ & $0.353 \pm 0.069 g$ & $0.423 \pm 0.004 \mathrm{a}$ \\
\hline$\Delta h c p-2$ & $81.67 \pm 7.778 \mathrm{a}$ & $1.733 \pm 0.078 \mathrm{c}$ & $0.417 \pm 0.011 \mathrm{ab}$ \\
\hline$\Delta t s s L-3$ & $15 \pm \mathbf{3 . 3 3} \mathrm{d}$ & $0.92 \pm 0.1337 f$ & $0.303 \pm 0.012 \mathrm{ab}$ \\
\hline$\Delta t s s K-2$ & $18.3 \pm 5.56 d$ & $1.34 \pm \mathbf{0 . 1 6 7} \mathrm{de}$ & $0.071 \pm 0.046 g$ \\
\hline
\end{tabular}

y Values within virulence, amylovoran production, and levan production followed by the same letter are not significantly different according to one-way Student's $t$ test $(P=0.05) . \mathrm{OD}_{600}=$ optical density at $600 \mathrm{~nm}$. Numbers in bold indicate reduced compared with the WT and numbers in italics indicate increased compared with the WT.

$\mathrm{z}$ T6SS = type VI secretion system. 


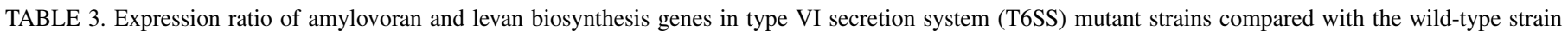

\begin{tabular}{|c|c|c|c|c|c|c|}
\hline \multirow[b]{2}{*}{ Strain } & \multicolumn{6}{|c|}{ Genes } \\
\hline & $a m s B\left(E A M Y \_2249\right)$ & amsD (EAMY_2247) & amsE (EAMY_2246) & amsG(EAMY_2253) & amsJ (EAMY_2244) & lsc (EAMY_3695) \\
\hline \multicolumn{7}{|l|}{ T6SS-1 } \\
\hline$\Delta v g r G-2$ & $0.51 \pm 0.07$ & $0.50 \pm 0.13$ & $0.53 \pm 0.18$ & $0.57 \pm 0.10$ & $0.53 \pm 0.12$ & $1.07 \pm 0.18$ \\
\hline$\Delta v \operatorname{gr} G-1$ & $0.47 \pm 0.16$ & $0.52 \pm 0.10$ & $0.51 \pm 0.14$ & $0.43 \pm 0.16$ & $0.50 \pm 0.11$ & $1.20 \pm 0.07$ \\
\hline$\Delta c l p V-1$ & $1.04 \pm 0.16$ & $1.03 \pm 0.17$ & $1.03 \pm 0.16$ & $0.93 \pm 0.18$ & $0.87 \pm 0.16$ & $1.02 \pm 0.18$ \\
\hline$\Delta t s s G-1$ & $0.25 \pm 0.09$ & $0.21 \pm 0.01$ & $0.43 \pm 0.07$ & $0.40 \pm 0.05$ & $0.44 \pm 0.08$ & $0.52 \pm 0.06$ \\
\hline$\Delta t s s F-1$ & $1.03 \pm 0.17$ & $1.00 \pm 0.08$ & $1.07 \pm 0.19$ & $1.01 \pm 0.14$ & $0.89 \pm 0.14$ & $0.51 \pm 0.07$ \\
\hline$\Delta t s s E-1$ & $1.10 \pm 0.06$ & $1.05 \pm 0.15$ & $1.14 \pm 0.04$ & $1.16 \pm 0.12$ & $0.96 \pm 0.16$ & $0.12 \pm 0.06$ \\
\hline$\Delta \operatorname{tag} H-1$ & $1.07 \pm 0.18$ & $0.97 \pm 0.11$ & $0.80 \pm 0.20$ & $0.83 \pm 0.04$ & $0.92 \pm 0.19$ & $0.16 \pm 0.08$ \\
\hline$\Delta h c p-1$ & $3.63 \pm 0.29$ & $3.40 \pm 0.27$ & $3.77 \pm 0.29$ & $3.23 \pm 0.51$ & $3.50 \pm 0.47$ & $0.20 \pm 0.05$ \\
\hline$\Delta t s s C-1$ & $2.57 \pm 0.42$ & $3.40 \pm 0.27$ & $3.27 \pm 0.32$ & $3.03 \pm 0.31$ & $3.02 \pm 0.33$ & $1.01 \pm 0.07$ \\
\hline$\Delta t s s B-1$ & $2.53 \pm 0.44$ & $2.53 \pm 0.58$ & $2.41 \pm 0.27$ & $2.63 \pm 0.42$ & $2.73 \pm 0.22$ & $1.07 \pm 0.06$ \\
\hline$\Delta t s s A-1$ & $2.67 \pm 0.44$ & $2.37 \pm 0.42$ & $2.70 \pm 0.33$ & $2.67 \pm 0.24$ & $2.77 \pm 0.18$ & $0.54 \pm 0.09$ \\
\hline$\Delta t s s M-1$ & $0.83 \pm 0.05$ & $0.88 \pm 0.14$ & $1.09 \pm 0.14$ & $0.86 \pm 0.08$ & $0.83 \pm 0.10$ & $0.16 \pm 0.04$ \\
\hline$\Delta t s s L-1$ & $0.95 \pm 0.17$ & $1.10 \pm 0.14$ & $1.16 \pm 0.12$ & $0.84 \pm 0.04$ & $1.02 \pm 0.12$ & $1.07 \pm 0.02$ \\
\hline$\Delta t s s K-1$ & $0.42 \pm 0.09$ & $0.34 \pm 0.04$ & $0.40 \pm 0.06$ & $0.49 \pm 0.06$ & $0.52 \pm 0.05$ & $0.22 \pm 0.07$ \\
\hline$\Delta t s s J-1$ & $1.19 \pm 0.04$ & $1.01 \pm 0.09$ & $0.90 \pm 0.15$ & $1.09 \pm 0.16$ & $1.09 \pm 0.13$ & $1.10 \pm 0.15$ \\
\hline \multicolumn{7}{|l|}{ T6SS-2 } \\
\hline$\Delta \operatorname{tag} H-2$ & $0.99 \pm 0.09$ & $1.10 \pm 0.20$ & $1.01 \pm 0.15$ & $0.91 \pm 0.07$ & $0.89 \pm 0.02$ & $0.62 \pm 0.09$ \\
\hline$\Delta t s s M-2$ & $1.01 \pm 0.14$ & $0.83 \pm 0.05$ & $0.89 \pm 0.13$ & $0.87 \pm 0.08$ & $1.10 \pm 0.14$ & $1.08 \pm 0.13$ \\
\hline$\Delta t s s L-2$ & $0.97 \pm 0.16$ & $0.95 \pm 0.17$ & $0.87 \pm 0.16$ & $0.88 \pm 0.05$ & $0.94 \pm 0.12$ & $1.14 \pm 0.11$ \\
\hline \multicolumn{7}{|l|}{ T6SS-3 } \\
\hline$\Delta t s s A-3$ & $0.28 \pm 0.05$ & $0.43 \pm 0.09$ & $0.45 \pm 0.04$ & $0.42 \pm 0.02$ & $0.53 \pm 0.04$ & $0.85 \pm 0.10$ \\
\hline$\Delta t s s E-2$ & $0.33 \pm 0.02$ & $0.31 \pm 0.06$ & $0.44 \pm 0.05$ & $0.44 \pm 0.02$ & $0.51 \pm 0.02$ & $0.88 \pm 0.09$ \\
\hline$\Delta v \operatorname{gr} G-4$ & $0.96 \pm 0.16$ & $1.10 \pm 0.20$ & $0.91 \pm 0.14$ & $0.97 \pm 0.16$ & $0.97 \pm 0.12$ & $1.03 \pm 0.11$ \\
\hline$\Delta t s s J-2$ & $0.38 \pm 0.10$ & $0.28 \pm 0.05$ & $0.32 \pm 0.05$ & $0.41 \pm 0.04$ & $0.37 \pm 0.08$ & $0.50 \pm 0.11$ \\
\hline$\Delta t s s G-2$ & $0.22 \pm 0.05$ & $0.30 \pm 0.06$ & $0.34 \pm 0.09$ & $0.28 \pm 0.05$ & $0.37 \pm 0.11$ & $0.97 \pm 0.16$ \\
\hline$\Delta t s s F-2$ & $0.35 \pm 0.09$ & $0.30 \pm 0.07$ & $0.32 \pm 0.05$ & $0.39 \pm 0.02$ & $0.34 \pm 0.05$ & $1.07 \pm 0.22$ \\
\hline$\Delta t s s A-2$ & $0.38 \pm 0.08$ & $0.40 \pm 0.07$ & $0.37 \pm 0.04$ & $0.45 \pm 0.06$ & $0.35 \pm 0.03$ & $1.13 \pm 0.24$ \\
\hline$\Delta t s s M-3$ & $0.28 \pm 0.05$ & $0.35 \pm 0.11$ & $0.48 \pm 0.10$ & $0.36 \pm 0.06$ & $0.40 \pm 0.11$ & $1.03 \pm 0.11$ \\
\hline$\Delta v \operatorname{gr} G-3$ & $0.92 \pm 0.19$ & $1.21 \pm 0.06$ & $1.01 \pm 0.20$ & $0.98 \pm 0.18$ & $1.07 \pm 0.18$ & $0.87 \pm 0.04$ \\
\hline$\Delta c l p V-2$ & $0.28 \pm 0.05$ & $0.25 \pm 0.05$ & $0.40 \pm 0.08$ & $0.35 \pm 0.04$ & $0.38 \pm 0.09$ & $0.89 \pm 0.06$ \\
\hline$\Delta h c p-2$ & $1.10 \pm 0.07$ & $1.03 \pm 0.16$ & $0.87 \pm 0.05$ & $1.07 \pm 0.12$ & $1.14 \pm 0.10$ & $0.97 \pm 0.16$ \\
\hline$\Delta t s s L-3$ & $0.40 \pm 0.06$ & $0.35 \pm 0.04$ & $0.33 \pm 0.04$ & $0.46 \pm 0.04$ & $0.46 \pm 0.06$ & $1.02 \pm 0.12$ \\
\hline$\Delta t s s K-2$ & $0.47 \pm 0.24$ & $0.53 \pm 0.42$ & $0.50 \pm 0.20$ & $0.37 \pm 0.29$ & $0.43 \pm 0.11$ & $0.34 \pm 0.14$ \\
\hline$\Delta t s s C-2$ & $0.43 \pm 0.11$ & $0.41 \pm 0.06$ & $0.42 \pm 0.10$ & $0.31 \pm 0.03$ & $0.43 \pm 0.08$ & $0.93 \pm 0.11$ \\
\hline$\Delta t s s B-2$ & $0.30 \pm 0.06$ & $0.32 \pm 0.06$ & $0.40 \pm 0.07$ & $0.29 \pm 0.06$ & $0.44 \pm 0.06$ & $1.07 \pm 0.18$ \\
\hline
\end{tabular}

with that of the WT strain; however, we still do not have a reasonable explanation as to why some genes but not the others are involved in EPS production. Future mechanism studies are needed to clarify this. In summary, we provided evidence that T6SS function in bacterial competition in Erwinia amylovora strain NCPPB1665. Our data also provided experimental evidence that T6SS play an important role in virulence, possibly by affecting EPS production in E. amylovora. Future works should focus on determining the molecular mechanisms as to how T6SS affect EPS production and, thus, virulence. Identification of T6SS effectors in E. amylovora may further provide insight into the roles of T6SS in bacterial competition, EPS production, and virulence.

\section{ACKNOWLEDGMENTS}

This study was supported by the National Natural Science Foundation of China (number 31500107) and China Postdoctoral Science Foundation (project number 2015M570461).

\section{LITERATURE CITED}

Aschtgen, M. S., Gavioli, M., Dessen, A., Lloubès, R., and Cascales, E. 2010. The SciZ protein anchors the enteroaggregative Escherichia coli type VI secretion system to the cell wall. Mol. Microbiol. 75:886-899.

Ayers, A. R., Ayers, S. B., and Goodman, R. N. 1979. Extracellular polysaccharide of Erwinia amylovora: A correlation with virulence. Appl. Environ. Microbiol. 38:659-666.

Bellemann, P., Bereswill, S., Berger, S., and Geider, K. 1994. Visualization of capsule formation by Erwinia amylovora and assays to determine amylovoran synthesis. Int. J. Biol. Macromol. 16:290-296.

Bingle, L. E. H., Bailey, C. M., and Pallen, M. J. 2008. Type VI secretion: A beginner's guide. Curr. Opin. Microbiol. 11:3-8.
Blondel, C. J., Yang, H. J., Castro, B., Chiang, S., Toro, C. S., Zaldívar, M., Contreras, I., Andrews-Polymenis, H. L., and Santiviago, C. A. 2010. Contribution of the type VI secretion system encoded in SPI-19 to chicken colonization by Salmonella enterica serotypes Gallinarum and Enteritidis. PLoS One 5:e11724.

Bönemann, G., Pietrosiuk, A., Diemand, A., Zentgraf, H., and Mogk, A. 2009. Remodelling of VipA/VipB tubules by $\mathrm{ClpV}$-mediated threading is crucial for type VI protein secretion. EMBO J. 28:315-325.

Boyer, F., Fichant, G., Berthod, J., Vandenbrouck, Y., and Attree, I. 2009. Dissecting the bacterial type VI secretion system by a genome wide in silico analysis: What can be learned from available microbial genomic resources? BMC Genomics 10:104.

Bröms, J. E., Ishikawa, T., Wai, S. N., and Sjöstedt, A. 2013. A functional VipA-VipB interaction is required for the type VI secretion system activity of Vibrio cholera O1 strain A1552. BMC Microbiol. 13:96.

Calvin, L., and Krissoff, B. 1998. Technical barriers to trade: A case study of phytosanitary barriers and U.S.-Japanese apple trade. J. Agric. Resour. Econ. 23:351-366.

Christie, P. J., Amakuri, K., Krishnamoorthy, V., Jakubowski, S., and Cascales, E. 2005. Biogenesis, architecture, and function of bacterial type IV secretion systems. Annu. Rev. Microbiol. 59:451-485.

Cornelis, G. R. 2006. The type III secretion injectisome. Nat. Rev. Microbiol. 4:811-825.

De Maayer, P., Venter, S. N., Kamber, T., Duffy, B., Coutinho, T. A., and Smits, T. H. M. 2011. Comparative genomics of the type VI secretion systems of Pantoea and Erwinia species reveals the presence of putative effector islands that may be translocated by the VgrG and Hcp proteins. BMC Genomics 12:576.

Denny, T. P. 1995. Involvement of bacterial polysaccharides in plant pathogenesis. Annu. Rev. Phytopathol. 33:173-197.

Dong, T. G., Ho, B. T., Yoder-Himes, D. R., and Mekalanos, J. J. 2013. Identification of T6SS-dependent effector and immunity proteins by Tnseq in Vibrio cholerae. Proc. Natl. Acad. Sci. USA 110:2623-2628.

Eastgate, J. A., Taylor, N., Coleman, M. J., Healy, B., Thompson, L., and Roberts, I. S. 1995. Cloning, expression, and characterization of the lon 
gene of Erwinia amylovora: Evidence for a heat shock response. J. Bacteriol. 177:932-937.

Edmunds, A. C., Castiblanco, L. F., Sundin, G. W., and Waters, C. M. 2013. Cyclic Di-GMP modulates the disease progression of Erwinia amylovora. J. Bacteriol. 195:2155-2165.

Filloux, A., Hachani, A., and Bleves, S. 2008. The bacterial type VI secretion machine: Yet another player for protein transport across membranes. Microbiology 154:1570-1583.

Gross, M., Geier, G., Rudolph, K., and Geider, K. 1992. Levan and levansucrase synthesized by the fire blight pathogen Erwinia amylovora. Physiol. Mol. Plant Pathol. 40:371-381.

Hachani, A., Lossi, N. S., and Filloux, A. 2013. A visual assay to monitor T6SS-mediated bacterial competition. J. Vis. Exp. 73:e50103.

Hildebrand, M., Aldridge, P., and Geider, K. 2006. Characterization of hns genes from Erwinia amylovora. Mol. Genet. Genomics 275:310-319.

Ho, B. T., Dong, T. G., and Mekalanos, J. J. 2014. A view to a kill: The bacterial type VI secretion system. Cell Host Microbe 15:9-21.

Hoang, T. T., Karkhoff-Schweizer, R. R., Kutchma, A. J., and Schweizer, H. P. 1998. A broad-host-range Flp-FRT recombination system for site-specific excision of chromosomally-located DNA sequences: Application for isolation of unmarked Pseudomonas aeruginosa mutants. Gene 212:77-86.

Hood, R. D., Singh, P., Hsu, F., Güvener, T., Carl, M. A., Trinidad, R. R., Silverman, J. M., Ohlson, B. B., Hicks, K. G., Plemel, R. L., Li, M., Schwarz, S., Wang, W. Y., Merz, A. J., Goodlett, D. R., and Mougous, J. D. 2010. A type VI secretion system of Pseudomonas aeruginosa targets a toxin to bacteria. Cell Host Microbe 7:25-37.

Hsu, F., Schwarz, S., and Mougous, J. D. 2009. TagR promotes PpkAcatalysed type VI secretion activation in Pseudomonas aeruginosa. Mol. Microbiol. 72:1111-1125.

Ishikawa, T., Sabharwal, D., Broms, J., Milton, D. L., Sjostedt, A., Uhlin, B. E., and Wai, S. N. 2012. Pathoadaptive conditional regulation of the type VI secretion system in Vibrio cholerae O1 strains. Infect. Immun. 80:575-584.

Jock, S., Donat, V., Lopez, M. M., Bazzi, C., and Geider, K. 2002. Following spread of fire blight in Western, Central and Southern Europe by molecular differentiation of Erwinia amylovora strains with PFGE analysis. Environ. Microbiol. 4:106-114.

Kovach, M. E., Elzer, P. H., Hill, D. S., Robertson, G. T., Farris, M. A., Roop, R. M., and Peterson, K. M. 1995. Four new derivatives of the broad-hostrange cloning vector $\mathrm{pBBR} 1 \mathrm{MCS}$, carrying different antibiotic-resistance cassettes. Gene 166:175-176.

Leung, K. Y., Siame, B. A., Tenkink, B. J., Noort, R. J., and Mok, Y. K. 2011. Type VI secretion regulation: Crosstalk and intracellular communication. Curr. Opin. Microbiol. 14:9-15.

Ma, L. S., Hachani, A., Lin, J., Filloux, A., and Lai, E. 2014. Agrobacterium tumefaciens deploys a superfamily of type IV secretion DNase effectors as weapons for interbacterial competition in planta. Cell Host Microbe 16: 94-104.

Mann, R. A., Smits, T. H., Bühlmann, A., Blom, J., Goesmann, A., Frey, J. E., Plummer, K. M., Beer, S. V., Luck, J., Duffy, B., and Rodoni, B. 2013. Comparative genomics of 12 strains of Erwinia amylovora identifies a pangenome with a large conserved core. PLoS One 8:e55644.

Matthysse, A. G., Yarnall, H. A., and Young, N. 1996. Requirement for genes with homology to $\mathrm{ABC}$ transport systems for attachment and virulence of Agrobacterium tumefaciens. J. Bacteriol. 178:5302-5308.

Mattinen, L., Nissinen, R., Riipi, T., Kalkkinen, N., and Pirhonen, M. 2007. Host-extract induced changes in the secretome of the plant pathogenic bacterium Pectobacterium atrosepticum. Proteomics 7:3527-3537.

McNally, R. R., Toth, I. K., Cock, P. J., Pritchard, L., Hedley, P. E., Morris, J. A., Zhao, Y., and Sundin, G. W. 2012. Genetic characterization of the HrpL regulation of the fire blight pathogen Erwinia amylovora reveals novel virulence factors. Mol. Plant Pathol. 13:160-173.

Mougous, J. D., Cuff, M. E., Raunser, S., Shen, A., Zhou, M., Gifford, C. A., Goodman, A. L., Joachimiak, G., Ordoñez, C. L., Lory, S., Walz, T., Joachimiak, A., and Mekalanos, J. J. 2006. A virulence locus of Pseudomonas aeruginosa encodes a protein secretion apparatus. Science 312:1526-1530.

Myung, I.-S., Lee, J.-Y., Yun, M.-J., Lee, Y.-H., Lee, Y.-K., Park, D.-H. and Oh, C.-S. 2016. Fire blight of apple, caused by Erwinia amylovora, a new disease in Korea. Plant Dis. 100:1774.

Ordax, M., Marco-Noales, E., López, M. M., and Biosca, E. G. 2010. Exopolysaccharides favor the survival of Erwinia amylovora under copper stress through different strategies. Res. Microbiol. 161:549-555.

Pukatzki, S., Ma, A. T., Revel, A. T., Sturtevant, D., and Mekalanos, J. J. 2007. Type VI secretion system translocates a phage tail spike-like protein into target cells where it cross-links actin. Proc. Natl. Acad. Sci. USA 104:15508-15513.

Pukatzki, S., Ma, A. T., Sturtevant, D., Krastins, B., Sarracino, D., Nelson, W. C., Heidelberg, J. F., and Mekalanos, J. J. 2006. Identification of a conserved bacterial protein secretion system in Vibrio cholera using the Dictyostelium host model system. Proc. Natl. Acad. Sci. USA 103:1528-1533.
Pukatzki, S., McAuley, S. B., and Miyata, S. T. 2009. The type VI secretion system: Translocation of effectors and effector-domains. Curr. Opin. Microbiol. 12:11-17.

Records, A. R. 2011. The type VI secretion system: A multipurpose delivery system with a phage-like machinery. Mol. Plant-Microbe Interact. 24:751-757.

Records, A. R., and Gross, D. C. 2010. Sensor kinases RetS and LadS regulate Pseudomonas syringae type VI secretion and virulence factors. J. Bacteriol. 192:3584-3596.

Sarris, P. F., Trantas, E. A., Skandalis, N., Tampakaki, A. P., Kapanidou, M., Kokkinidis, M., and Panopoulos, N. J. 2012. Phytobacterial type VI secretion system-Gene distribution, phylogeny, structure and biological functions. Pages 53-84 in: Plant Pathology. C. J. R. Cumagun, ed. InTech.

Schwarz, S., Hood, R. D., and Mougous, J. D. 2010. What is type VI secretion doing in all those bugs? Trends Microbiol. 18:531-537.

Segal, G., Feldman, M., and Zusman, T. 2005. The Icm/Dot type-IV secretion systems of Legionella pneumophila and Coxiellaburnetii. FEMS Microbiol. Rev. 29:65-81.

Shneider, M. M., Buth, S. A., Ho, B. T., Basler, M., Mekalanos, J. J., and Leiman, P. G. 2013. PAAR-repeat proteins sharpen and diversify the type VI secretion system spike. Nature 500:350-353.

Shyntum, D. Y., Theron, J., Venter, S. N., Moleleki, L. N., Toth, I. K., and Coutinho, T. A. 2015. Pantoea ananatis utilizes a type VI secretion system for pathogenesis and bacterial competition. Mol. Plant-Microbe Interact. 28:420-431.

Silverman, J. M., Austin, L. S., Hsu, F., Hicks, K. G., Hood, R. D., and Mougous, J. D. 2011. Separate inputs modulate phosphorylation-dependent and -independent type VI secretion activation. Mol. Microbiol. 82:1277-1290.

Simon, R., Priefer, U., and Pühler, A. 1983. A broad host range mobilization system for in vivo genetic engineering: Transposon mutagenesis in gram negative bacteria. Nat. Biotechnol. 1:784-791.

Sjulin, T. M., and Beer, S. V. 1978. Mechanism of wilt induction by amylovoran in Cotoneaster shoots and its relation to wilting of shoots infected by Erwinia amylovora. Phytopathology 68:89-94.

Smits, T. H. M., Rezzonico, F., Kamber, T., Blom, J., Goesmann, A., Frey, J. E., and Duffy, B. 2010. Complete genome sequence of the fire blight pathogen Erwinia amylovora CFBP 1430 and comparison to other Erwinia spp. Mol. Plant-Microbe Interact. 23:384-393.

Steinberger, E. M. 1988. Creation and complementation of pathogenicity mutants of Erwinia amylovora. Mol. Plant-Microbe Interact. 1:135-144.

Suarez, G., Sierra, J. C., Sha, J., Wang, S., Erova, T. E., Fadl, A. A., Foltz, S. M., Horneman, A. J., and Chopra, A. K. 2008. Molecular characterization of a functional type VI secretion system from a clinical isolate of Aeromonas hydrophila. Microb. Pathog. 44:344-361.

Tian, Y., Zhao, Y., Wu, X., Liu, F., Hu, B., and Walcott, R. R. 2015. The type VI protein secretion system contributes to biofilm formation and seed-to-seedling transmission of Acidovorax citrulli on melon. Mol. Plant Pathol. 16:38-47.

van der Zwet, T. 2006. Present worldwide distribution of fire blight and closely related disease. Acta Hortic. 704:35-36.

Vanneste, J. L., ed. 2000. Fire Blight: The Disease and Its Causative Agent, Erwinia amylovora. CABI Publishing, New York.

Vrancken, K., Holtappels, M., Schoofs, H., Deckers, T., and Valcke, R. 2013. Pathogenicity and infection strategies of the fire blight pathogen Erwinia amylovora in Rosaceae: State of the art. Microbiology 159:823-832.

Wang, D., Korban, S. S., Pusey, P. L., and Zhao, Y. 2012. AmyR Is a novel negative regulator of amylovoran production in Erwinia amylovora. PLoS One 7:e45038.

Weber, B., Hasic, M., Chen, C., Wai, S. N., and Milton, D. L. 2009. Type VI secretion modulates quorum sensing and stress response in Vibrio anguillarum. Environ. Microbiol. 11:3018-3028.

Wu, H. Y., Chung, P. C., Shih, H. W., Wen, S. R., and Lai, E. M. 2008. Secretome analysis uncovers an Hcp-family protein secreted via a type VI secretion system in Agrobacterium tumefaciens. J. Bacteriol. 190:2841-2850.

Zeng, Q., McNally, R. R., and Sundin, G. W. 2013. Global small RNA chaperone Hfq and regulatory small RNAs are important virulence regulators in Erwinia amylovora. J. Bacteriol. 195:1706-1717.

Zhang, H. B., Wang, L. H., and Zhang, L. H. 2002. Genetic control of quorumsensing signal turnover in Agrobacterium tumefaciens. Proc. Natl. Acad. Sci. USA 99:4638-4643.

Zhao, Y., Wang, D., Nakka, S., Sundin, G. W., and Korban, S. S. 2009. Systems-level analysis of two-component signal transduction systems in Erwinia amylovora: Role in virulence, regulation of amylovoran biosynthesis and swarming motility. BMC Genomics 10:245.

Zheng, J., Ho, B., and Mekalanos, J. J. 2011. Genetic analysis of anti-amoebae and anti-bacterial activities of the type VI secretion system in Vibrio cholerae. PLoS One 6:e23876.

Zheng, J., and Leung, K. Y. 2007. Dissection of a type VI secretion system in Edwardsiella tarda. Mol. Microbiol. 66:1192-1206.

Zou, L. F., Li, Y. R., and Chen, G. Y. 2011. A non-marker mutagenesis strategy to generate poly-hrp gene mutants in the rice pathogen Xanthomonas oryzae pv. oryzicola. Agric. Sci. China 10:1139-1150. 